\title{
Genome-Edited T Cell Therapies
}

\author{
Juliette M. K. M. Delhove ${ }^{1}$ - Waseem Qasim ${ }^{1}$ \\ Published online: 18 April 2017 \\ (C) The Author(s) 2017. This article is published with open access at Springerlink.com
}

\begin{abstract}
Purpose of Review Alternative approaches to conventional drug-based cancer treatments have seen $\mathrm{T}$ cell therapies deployed more widely over the last decade. This is largely due to their ability to target and kill specific cell types based on receptor recognition. Introduction of recombinant $\mathrm{T}$ cell receptors (TCRs) using viral vectors and HLA-independent $\mathrm{T}$ cell therapies using chimeric antigen receptors (CARs) are discussed. This article reviews the tools used for genome editing, with particular emphasis on the applications of sitespecific DNA nuclease mediated editing for T cell therapies. Recent Findings Genetic engineering of $\mathrm{T}$ cells using TCRs and CARs with redirected antigen-targeting specificity has resulted in clinical success of several immunotherapies. In conjunction, the application of genome editing technologies has resulted in the generation of HLA-independent universal $T$ cells for allogeneic transplantation, improved $T$ cell sustainability through knockout of the checkpoint inhibitor, programmed cell death protein-1 (PD-1), and has shown efficacy as an antiviral therapy through direct targeting of viral genomic sequences and entry receptors.

Summary The combined use of engineered antigen-targeting moieties and innovative genome editing technologies have recently shown success in a small number of clinical trials targeting HIV and hematological malignancies and are now being incorporated into existing strategies for other immunotherapies.
\end{abstract}

This article is part of the Topical Collection on Genome Editing

Waseem Qasim

w.qasim@ucl.ac.uk

1 Molecular Immunology Unit, UCL Great Ormond Street Institute of Child Health, University College London (UCL), 30 Guilford Street, London WC1N 1EH, UK
Keywords Genome editing · CRISPR/Cas9 - T cell therapies - Chimeric antigen receptors $\cdot$ T cell receptors Clinical trials · Immunotherapy

\section{Introduction}

T cell-based immunotherapies aim to target and lyse antigenpositive cells without detrimental effects to healthy cells. Early approaches focused on adoptive cell therapy (ACT), involving collection of potent antitumor T cells, ex vivo expansion, and reinfusion in an autologous fashion [1]. More recently, $T$ cells have been genetically altered to express modified $\alpha \beta$ T cell receptors (TCRs) that confer higher affinity for tumor antigen [2]. These TCRs recognize cell-surface and intracellular processed peptides presented in the context of self-major histocompatibility complex (MHC). Alternative synthetic constructs known as chimeric antigen receptors (CARs) employ antibody-derived antigen-binding variable heavy and light chain domains and operate in a HLAindependent manner. Genome editing technologies are now being applied to confer additional properties to engineered $T$ cells, with the first clinical applications recently reported. This chapter reviews emerging gene editing tools and then presents the applications of such gene-edited T cells.

\section{Tools}

\section{Genome Editing Technologies}

Engineered nucleases incorporate customizable sequencespecific DNA-binding elements bound to nonspecific cleavage domains [3]. Induction of a nuclease-mediated doublestranded DNA break (DSB) results in the activation of 
endogenous DNA damage response pathways. Repair occurs in the presence of a suitable DNA template mediated by homology-directed repair (HDR) [4]. In the absence of template, the alternative error-prone nonhomologous end joining (NHEJ) pathway creates insertions or deletions (Indels) at the break point [5]. Indels can yield mRNA transcripts that contain frame-shift and nonsense mutations that undergo degradation through nonsense-mediated decay resulting in disruption of gene function [6]. Four major platforms are currently exploited for site-specific DNA-editing purposes: meganucleases, zinc finger nucleases (ZFNs), transcription activator-like effector (TALE)-nucleases (TALENs), and most recently the clustered regularly interspaced short palindromic repeats (CRISPR/Cas) system.

\section{Meganucleases}

Meganucleases are homing endonucleases derived from ICreI [7] and I-CeuI [8] and operate as homodimers that recognize DNA sequences with palindromic sequences. Variants containing two motifs, such as I-SceI, act as monomers consisting of a pair of nuclease domains with symmetryindependent targeting [9]. DNA recognition domains have a range of between 14 and $40 \mathrm{bp}$, leading to double-stranded DNA cleavage, generating 3' cohesive ends with 4 bp overhangs (Fig. 1a), a feature that may favor recombinogenic HDR compared to other methods (discussed later). This cleavage event initiates the transposition of the endonuclease mobile sequence into the cut site, a mechanism termed "homing" [14]. Site-specific meganucleases have challenging design criteria owing to the single-chained recognition and cleavage domains, although successful modification has been described for a number of applications [15-17]. In the context of gene therapy, meganucleases have for example been modeled for targeted recombination and correction of the RAG1 gene associated with severe combined immunodeficiency (SCID) [18] in hematopoietic stem cells (HSCs) and the XPC gene associated with Xeroderma Pigmentosum in skin cells [19]. Applications within $\mathrm{T}$ cell therapies include prevention of graft-versus-host disease (GvHD) via meganucleasemediated TCR $\alpha$-chain knockout under conditions for optimal T cell stimulation and meganuclease cleavage efficiency [15]. While engineering of site-specific meganucleases has had some success, their use remains limited within mammalian cells, largely due to complexity of design criteria.

\section{Zinc Finger Nucleases}

ZFNs are hybrid proteins consisting of a nonspecific FokI cleavage domain and a sequence-specific zinc finger protein that recognizes a predetermined genomic region. The FokI domain requires two DNA-binding events followed by dimerization in order to cleave DNA [20]. Linked to the FokI domain is a zinc finger that consists of approximately 30 amino acids arranged in a $\beta \beta \alpha$ configuration. Each zinc finger recognizes approximately $3 \mathrm{bp}$ and binds to the DNA through insertion of the $\alpha$-helix into the DNA major groove [21] (Fig. 1b). A modular-targeting array binds to specified sequences with high affinity and catalytically induces DNA cleavage and subsequent DNA repair that ultimately results in gene disruption or template-mediated HDR. The specificity of the ZFN may be context-dependent, which adds another level of design complexity [22]. Off-target events are known to occur [23], with obligate heterodimerizing Fok1 [20] helping to address this. Examples of future therapeutic applications include Sangamo BioSciences' targeting of the albumin gene locus in hepatocytes with in vivo applications for the treatment of Hemophilia A, Fabry disease, and Gaucher disease [24]. Trials are in progress for treatment of HIV (NCT01044654 and NCT01252641) and planned for hemophilia B (NCT02695160). Despite some early clinical applications using ZFNs, the difficulty of engineering ZFNs to produce domains with high specificity and affinity may be a limitation for wider deployment.

\section{TALENS}

TALEs are proteins secreted by bacterial plant pathogens such as Xanthomonas and Ralstonia sp. In 2009, two independent research groups detailed the mechanism of TALE DNA recognition $[25,26]$. They determined that polymorphisms occurred primarily within hypervariable amino acid residues, located at positions 12 and 13 within each tandem repeat. These residues were termed repeat-variable diresidues (RVDs) and corresponded to a single nucleotide target site [25]. Their codes are well-defined, with NN recognizing $\mathrm{G}$ or A, NI for A, HD for C, and NG for T [25, 26]. More recently, the RVD NH has also been shown to achieve robust guanine-specific recognition [27]. Further modifications to expand the RVD repertoire have subsequently been developed and have demonstrated substantially reduced off-target cleavage events [28]. The synthesis of a hybrid protein containing the TAL effector fused to the FokI DNA cleavage domain has resulted in the development of TALENs (Fig. 1c).

Advantages of TALENs over ZFNs as a genome editing tool lies in their simpler design criteria compared to de novo synthesis of ZFNs. The lack of recognition code context dependency makes this technology more user-friendly, cost-effective, with more predictable targeting. Additionally, TALENs have demonstrated a higher genome-editing activity [29] while imposing less nuclease-associated toxicity, presumably owed to the lower off-target cleavage affects [30]. TALENs have been substantially utilized in T cell therapies against HIV [31], and virus-specific $\mathrm{T}$ cells with resistance to the immunosuppressive effects of corticosteroids have been developed 
A)

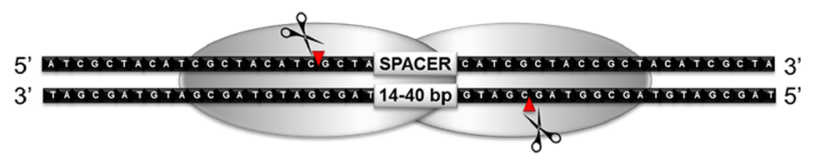

C)

TALEN

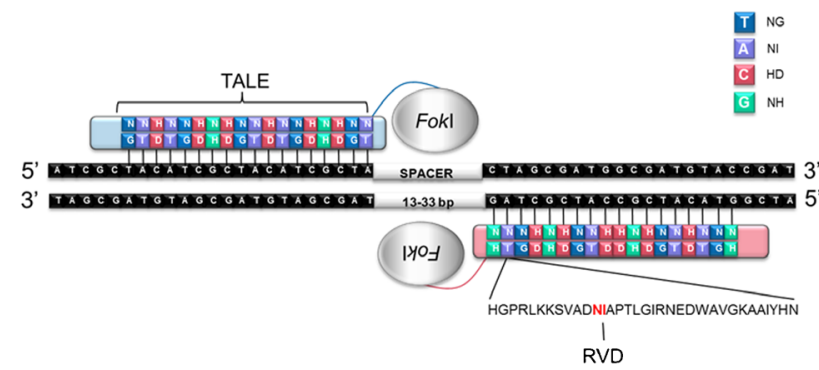

Fig. 1 Genome editing technologies. Introduction of double-stranded breaks enables the formation of Indels in the absence of a suitable repair template, leading to knockout of gene function. Several genome editing technologies are currently available, each with a specific mode of action. a Meganucleases are homing endonucleases that form dimers in order to cleave. The single nuclease domain is made up of the DNA recognition and cleavage domains. (from Bertoni C. Front. Physiol. 2014, 5:148) [10]. b ZFNs require dimerization of two Fok1 domains at targeted loci in order for scission to occur. Each zinc finger contacts three nucleotides of the target sequence. (from Didigu CA, Doms RW. Viruses

through glucocorticoid receptor knockout [32]. The first clinical application of $\mathrm{T}$ cells modified by TALENs has seen successful remission of leukemia in an 11-month-old infant [33••]. The disadvantages of TALENs, however, include the highly repetitive sequence and large size relative to ZFNs which may impede delivery, particularly via sizerestricted or reverse-transcribing vectors [34].

\section{CRISPR/Cas 9}

As an alternative to protein-guided methodologies, a number of nucleotide-mediated genome editing techniques have been developed, with the most common used being the CRISPR/Cas9 [35•] system, and more recently CRISPR/Cpf1 [36], and NgArgonaute [37]. While each has their advantages, CRISPR/Cas9 remains the most extensively characterized and widely used system to date. The CRISPR/Cas9 system is a component of the bacterial adaptive immune system used to distinguish between self and nonself. The combination of Cas9 and synthetic guide RNA (gRNA) has been harnessed to provide a twocomponent programmable system engineered for exploitation in a diverse range of molecular biology applications $[38,39 \bullet \bullet, 40 \bullet \cdot$. Cas 9 requires formation of a secondary structure via complementary base pairing of the trans-
B) $\quad$ ZFN

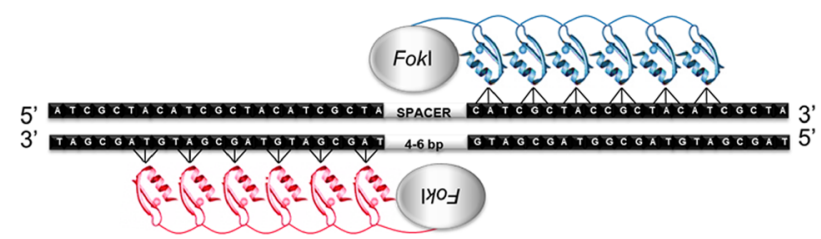

D) CRISPR/Cas 9

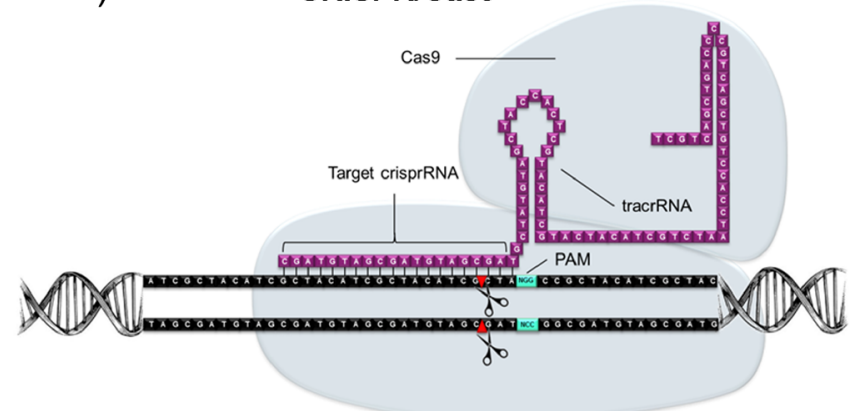

2012, 4(2), 309-324) [11]. c TALEN cleavage is also FokI mediated; however, each TALE contains 34 amino acid repeat sequences, with each RVD targeting a single base in the target sequence. (reprinted by permission from Macmillan Publishers Ltd.: Hyongbum K, Jin-Soo K. Nature Reviews Genetics 2014, 15, 321-334) [12]. d CRISPR/Cas9 technology is RNA-guided with Cas9 mediating double-stranded cleavage of the target site. The target site is flanked by a PAM sequence, with double-stranded cleavage occurring three bases upstream from this motif (from Agrotis A, Ketteler R. Front. Genet. 2015, 6:300) [13]

activating (tracrRNA) with the pre-crRNA. This RNA chimera triggers further processing of the crRNA by RNase and induces silencing of foreign DNA by Cas9 [41]. DNA targeting is determined by gRNA complementarity to the genome. The caveat to Cas9 cleavage is that a protospacer adjacent motif (PAM) sequence is required to be juxtaposed to the tracrRNA:crRNA secondary structure on the $3^{\prime}$ end. The Streptococcus pyogenes spCas9 consensus PAM sequence is 5'-NGG-3' which lies adjacent to the region of gRNA complementarity [41]. In the presence of Cas9 and its respective PAM, targeted cleavage of double-stranded DNA occurs between the 3rd and 4th base upstream of the PAM, leading to activation of the DNA damage response pathways [39・•] (Fig. 1d). Deactivated Cas9 (dCas9) variants have also been generated through incorporation of inactivating mutations in the Cas9 sequence. Fusions of dCas9 to chromatin modifying activation or repression domains permit regulation of gene expression in the absence of DSBs [42]. The CRISPR approach has risen as the tool of choice for genome editing applications due to its design simplicity, ease of use, and efficacy [43]. Trials of gene edited T cells in lung cancer patients are underway at Sichuan University in Chengdu, China and a US immunotherapy trial using CRISPR-mediated TCR knockout and TCR-modified T cells targeting melanoma, myeloma, and sarcoma has recently been proposed [44]. 


\section{Applications}

Adoptive immunotherapy relies on the isolation of antitumor lymphocytes, their ex vivo expansion, and subsequent infusion into patients. Naturally occurring tumor lymphocytes, however, have been shown to have weak immunogenicity and limited persistence. Genetic manipulation of $\mathrm{T}$ cells to express various tumor-targeting moieties has been extensively used to enhance their antigen avidity, specificity, and downstream effector functions. Harnessing the capabilities of genome editing technologies has further enhanced the scope of $\mathrm{T}$ cell therapies, particularly in the development of allogeneic universal $\mathrm{T}$ cells and antiviral therapies. Targets, implementation strategies and clinical efficacy of genome-edited $\mathrm{T}$ cell therapies shall be discussed in further depth in this section.

\section{TCR Redirected T Cells}

TCRs detect antigens that have been processed and presented as peptides on cell-surface MHC molecules, inducing activation of T cells in response to antigens. The TCR CD3 complex $(\mathrm{CD} 3 \varepsilon, \mathrm{CD} 3 \delta, \mathrm{CD} 3 \gamma$, and $\mathrm{CD} 3 \zeta)$ contains immunoreceptor tyrosine-based activation motifs (ITAMs) that remain dephosphorylated in resting T cells. Upon TCR ligation, the cytoplasmic tails of $\mathrm{CD} 3 \varepsilon$ and $\mathrm{CD} 3 \zeta$ undergo a conformational change rendering them accessible for phosphorylation via protein tyrosine kinases [45]. ITAM phosphorylation prompts recruitment of complexes involved in organizing effector molecules, allowing accurate spatiotemperal activation of affector signal transduction (Fig. 2a).

Tumor-associated antigens are often expressed during fetal development or at low levels on normal tissues, leading to central tolerance. The first TCR-redirected $\mathrm{T}$ cells were against the melanoma antigen, MART-1, which yielded a response rate of $13 \%$ [48]. Increased avidity TCRs were subsequently developed for MART-1 and gp100 with reported responses of 30 and $19 \%$, respectively [49]. The limited expression of the cancer-testis antigen, NY-ESO-1, also made this an ideal target antigen. TCRs against this antigen have been trialed in patients with metastatic synovial cell sarcoma (MSCS) and melanoma, with clinical responses reported in 4 of 6 patients with MSCS and 5 of 11 with melanoma, 2 of which demonstrated complete remission after 1 year (NCT00670748) [50]. The June group recently demonstrated sustained antitumor effects and $\mathrm{T}$ cell persistence using lentiviral delivery of the NY-ESO-1 targeting TCR within a multiple myeloma phase I/II trial (NCT01352286) [51•]. Also, anti-MAGE-A3 TCR T cells targeting metastatic cancer resulted in clinical regression in 5 of 9 patients; however, there were 2 fatalities and 3 cases of neurological complications, raising concerns for its use in subsequent immunotherapies (NCT01273181) [52].
TCR mispairing, where there is heterologous pairing between the endogenous and recombinant TCRs, is capable of generating novel-targeting specificities and inducing autoreactivity [53]. While codon optimization, murinization of human TCRs, and the addition of cysteine residues have been found to reduce mispairing [54], complete knockout of the endogenous TCR would be advantageous. Further work exploring genome editing to knockout endogenous $\mathrm{TCR} \alpha / \beta$ chains has been achieved using ZFNs [55, 56], TALENs [57, 58], megaTAL, and CRISPR/Cas [59] nucleases. Bonini et al. developed $\alpha$ - and $\beta$-chain specific ZFNs against endogenous TCR genes and subsequently introduced the Wilms tumor-1-specific TCR via lentiviral gene transfer. This resulted in high avidity lymphocytes which had reduced alloreactivity but superior expansion and antigen recognition compared to unedited, donor-matched cells that underwent TCR gene transfer alone both in vitro and in NSG mice [56]. Fehse and colleagues performed TCR knockout using TALENs delivered by electroporation of mRNA, resulting in 58 and $41 \%$ knockout of the $\alpha$ - and $\beta$-chains respectively in primary $\mathrm{T}$ cells [57]. Recently, researchers at UPenn gained approval for a phase I trial to generate and transplant autologous $\mathrm{T}$ cells devoid of both endogenous TCR and the checkpoint inhibitor, programmed cell death protein-1 (PD-1), using CRISPR, while simultaneously overexpressing a TCR against the NY-ESO-1 peptide [44]. These trials will aim to demonstrate improved biosafety profiles of TCR-edited $\mathrm{T}$ cells.

\section{CAR T Cell Therapies}

Tumor-associated target antigens are typically associated with MHCs, restricting $\mathrm{T}$ cell therapies to cancers expressing a particular antigen. Furthermore, tumor cells can downregulate HLA class I expression during tumor progression [60]. The need to develop receptors that could target a number of antigens in a MHC-independent manner was critical in the development of the first CAR [61, 62]. Eshhar et al. demonstrated that chimeric $T$ cell receptors in a cytotoxic $\mathrm{T}$ cell hybridoma could target in a nonMHC restricted manner giving CAR $\mathrm{T}$ cells the ability to directly and potently target tumors which share common target antigens [62].

Structurally, a CAR consists of up to four domains - the antigen recognition domain, a hinge domain, a transmembrane element, and the signaling endodomain (Fig. 2b). The chimeric single chain antibody fragment $(\mathrm{scFv})$ uses a linker to allow self-association of the variable heavy and light chains [63]. Coupling of the $\mathrm{scFv}$ to the signal-transducing TCR CD3 $\zeta$ chain confers therapeutic and potent effector function [64]. Activation of the endodomains induces $\mathrm{T}$ cell 
A)

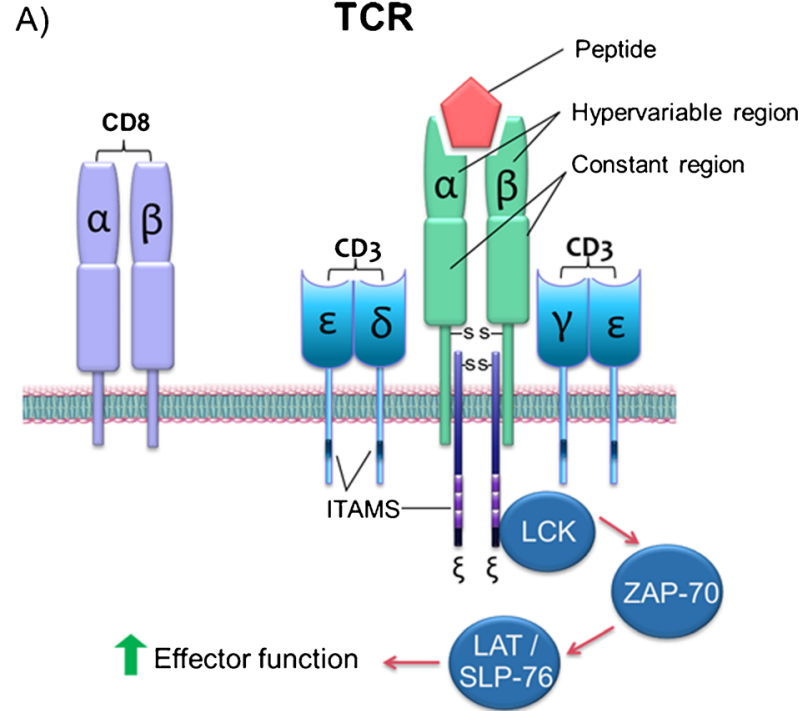

B) CAR

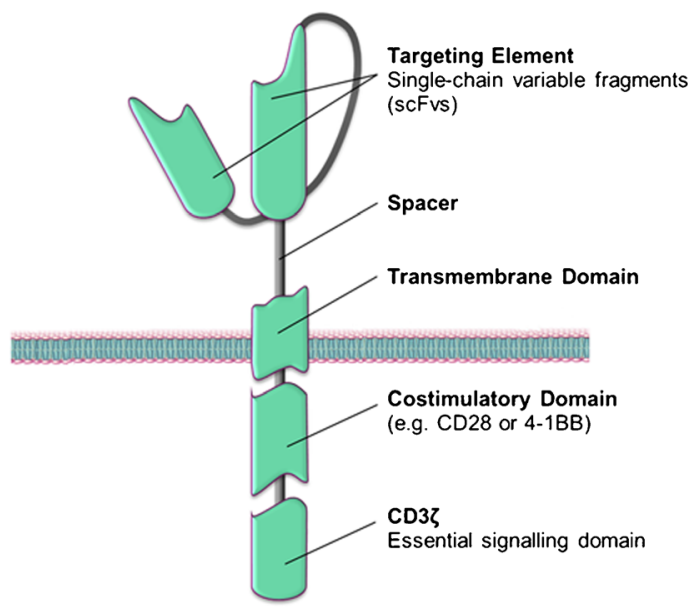

Fig. 2 Structure of TCRs and CARs. a The TCR is comprised of $\alpha$ and $\beta$ chains that closely associate with the $\varepsilon-\delta-\gamma$ - and $\zeta$-chains of the CD3 complex. Antigen-mediated activation of the $\alpha / \beta$ chains induces phosphorylation of the ITAMs by LCK. Subsequent activation of ZAP70 and its downstream targets, LAT and SLP-76, induces an intracellular signaling cascade resulting in the upregulation of genes associated with $\mathrm{T}$ cell effector function. (reprinted from Lineberry N, Fathman GC: Immunity 2006, 24(5):501-503, with permission from Elsevier) [46]. b Design of the chimeric antigen receptor includes the single-chain variable

activation, cytokine release, and non-MHC target cell lysis. Second-generation CARs were constructed to include a costimulatory domain arising from the CD28 or 4-1BB domain. Third-generation CARs were configured to express two co-stimulatory domains for enhanced $\mathrm{T}$ cell functionality and signal amplification [65].

In brief, the first clinical trials using CAR $\mathrm{T}$ therapies were against HIV [66] and subsequently metastatic ovarian [67] and renal cancers [68]. Rosenberg showed proof of clinical efficacy using CARs to treat lymphoma in a single patient in 2010 [69], while June and colleagues reported complete remission of $2 / 3$ patients treated using CARs against chronic lymphocytic leukemia in 2011 [70]. Sadelain et al. later published results demonstrating the antitumor efficacy of a CD19-CAR in 5 patients with relapsed B cell acute lymphoblastic leukemia (B-ALL) [71]. Cooper et al. genetically altered $\mathrm{T}$ cells to target $\mathrm{B}$ cell malignancies by expressing a CD19-specific CAR delivered by Sleeping Beauty transposition. Infusion of these modified T cells resulted in clinical responses in patients with ALL $(n=12)$ and B cell lymphoma $(n=13)$. This was the first clinical trial to employ the Sleeping Beauty transposon system for the delivery of a CD19-CAR to redirect specificity of isolated T cells [72]. We [73] and others [74] have reviewed trials involving CAR $\mathrm{T}$ cell therapies and their outcomes and highlighted key published trials using CAR T cells redirected against CD19 and CD20 (Table 1). fragment with antigen-binding affinity, fused to a spacer and transmembrane domain. Effector function is conferred via the TCR $\mathrm{CD} 3 \zeta$ domain, while the addition of one (2nd generation) or two (3rd generation) costimulatory domains drives signal activation and amplification of various effector signaling cascades (with permission from Juno Therapeutics: Chimeric Antigen Receptor Technology (CARs) https://www.junotherapeutics.com/our-science/car-technology/) [47]

\section{Gene-Edited CAR T Cells}

While CAR T cell therapies have demonstrated immense therapeutic potential, the cost implications and complexity of bespoke $\mathrm{T}$ cell therapies for autologous transplantation remains problematic for broader application. The development of a "universal" CAR T cell platform has recently harnessed the gene editing capabilities of TALENs in order to create an "offthe-shelf" adoptive $\mathrm{T}$ cell immunotherapy which was validated in vitro [58] and successfully applied to B-ALL [33••]. In order to overcome immune barriers intrinsic to allogeneic transplantations, targeted knockout of the endogenous $\alpha \beta$ TCR within donor-derived T cells was performed [91]. In this way, potential induction of GvHD was abrogated. CD52, which is highly expressed on mature B, T, and dendritic cells and is the target of the lymphodepleting CD52 monoclonal antibody, Alemtuzumab, was also targeted for gene disruption [92]. Therefore, CD52 negative cells survive host T cell depletion by Alemtuzumab [91]. Formal clinical trials are now underway in children and adults (NCT02808442, NCT02746952).

Additional targets include the extensively polymorphic HLA region encoding HLA class $1 \mathrm{~A}, \mathrm{~B}, \mathrm{C}$. In the absence of an HLA-identical donor, a HLA-matched unrelated donor may be available [93]. Genetic engineering of HLA expression provides a means of generating allogeneic cells and can be targeted directly (e.g., $\beta 2$-microglobulin 
Table 1 Published clinical trials using CD19/20 CAR T cells

\begin{tabular}{|c|c|c|c|c|c|c|c|c|c|}
\hline $\begin{array}{l}\text { Target } \\
\text { antigen }\end{array}$ & $\begin{array}{l}\text { Target } \\
\text { disease }\end{array}$ & $n$ & CAR structure & $\begin{array}{l}\text { Delivery } \\
\text { method }\end{array}$ & Origin of T cell & Cell dose & Trial number & Center & Reference \\
\hline CD19 & FL & 2 & $\mathrm{CD} 3 \zeta$ & $\mathrm{EP}$ & Autologous & $100-2000 \times 10^{6} / \mathrm{m}^{2}$ & NCT00182650 & $\mathrm{NCI}$ & Jensen (2010) [75] \\
\hline CD19 & FL & 1 & $\mathrm{CD} 28+\mathrm{CD} 3 \zeta$ & RV & Autologous & $5 \times 10^{6} / \mathrm{kg}$ & NCT00924326 & $\mathrm{NCI}$ & $\begin{array}{l}\text { Kochenderfer } \\
(2010)[69]\end{array}$ \\
\hline CD19 & $\begin{array}{l}\text { FL; } \\
\quad \text { DLBCL }\end{array}$ & 6 & $\mathrm{CD} 28+\mathrm{CD} 3 \zeta$ & RV & Autologous & $2-20 \times 10^{7} / \mathrm{m}^{2}$ & & $\mathrm{BCM}$ & Savoldo (2011) [76] \\
\hline CD19 & CLL; ALL & 10 & $\mathrm{CD} 28-\mathrm{CD} 3 \zeta$ & RV & Autologous & $\begin{array}{c}0.4,1,3 \times 10^{7} / \mathrm{kg} \\
\text { over } 2 \text { days }\end{array}$ & NCT01044069 & MSKCC & $\begin{array}{l}\text { Brentjens (2011) } \\
\quad[77]\end{array}$ \\
\hline CD19 & CLL & 3 & $4-1 \mathrm{BB}+\mathrm{CD} 3 \zeta$ & LV & Autologous & $0.15-16 \times 10^{6} / \mathrm{kg}$ & NCT01029366 & Upenn & $\begin{array}{l}\text { Porter (2011) [78]; } \\
\quad \text { Kalos (2011) [70] }\end{array}$ \\
\hline CD19 & CLL; ALL & 9 & $\mathrm{CD} 28+\mathrm{CD} 3 \zeta$ & RV & Autologous & $2-30 \times 10^{6} / \mathrm{kg}$ & NCT00466531 & MSKCC & $\begin{array}{l}\text { Brentjens (2011) } \\
\quad \text { [77] }\end{array}$ \\
\hline CD19 & $\begin{array}{l}\text { FL; CLL; } \\
\text { SMZL }\end{array}$ & 8 & $\mathrm{CD} 28+\mathrm{CD} 3 \zeta$ & $\mathrm{RV}$ & Autologous & $5-55 \times 10^{6} / \mathrm{kg}$ & NCT00924326 & $\mathrm{NCI}$ & $\begin{array}{l}\text { Kochenderfer } \\
\text { (2012) [79] }\end{array}$ \\
\hline CD19 & ALL & 5 & $\mathrm{CD} 28+\mathrm{CD} 3 \zeta$ & RV & Autologous & $1.5-3 \times 10^{6} / \mathrm{kg}$ & NCT01044069 & MSKCC & $\begin{array}{l}\text { Brentjens (2013) } \\
\text { [71] }\end{array}$ \\
\hline CD19 & $\begin{array}{l}\text { CLL; MCL; } \\
\text { DLBCL }\end{array}$ & 10 & $\mathrm{CD} 28+\mathrm{CD} 3 \zeta$ & $\mathrm{RV}$ & Allogeneic & $1-100 \times 10^{6} / \mathrm{kg}$ & NCT01087294 & $\mathrm{NCI}$ & $\begin{array}{l}\text { Kochenderfer } \\
(2013)[80]\end{array}$ \\
\hline CD19 & ALL; CLL & 8 & $\mathrm{CD} 28-\mathrm{CD} 3 \zeta$ & RV & Allogeneic & $\begin{array}{l}1.5,4.5 \\
12 \times 10^{7} / \mathrm{m}^{2}\end{array}$ & NCT00840853 & $\mathrm{BCM}$ & Cruz (2013) [81] \\
\hline CD19 & $\begin{array}{l}\text { CLL; ALL; } \\
\text { DLBCL; } \\
\text { FL; MCL }\end{array}$ & 110 & $4-1 \mathrm{BB}-\mathrm{CD} 3 \zeta$ & $\mathrm{RV}$ & Autologous & $\begin{array}{l}1.5-500 \times 10^{7} \text { total } \\
\text { cells }\end{array}$ & NCT01029366 & Upenn & Maude (2014) [82•] \\
\hline CD19 & ALL & 2 & 4-1BB-CD3ろ & LV & Autologous & $10-100 \times 10^{6} / \mathrm{kg}$ & NCT01626495 & Upenn & Maude (2014) [82•] \\
\hline CD19 & ALL & 30 & 4-1BB-CD3乙 & LV & Autologous & $0.76-20.6 \times 10^{6} / \mathrm{kg}$ & NCT01626495 & Upenn & Maude (2014) [82•] \\
\hline CD19 & ALL; CLL & 14 & $\mathrm{CD} 28-\mathrm{CD} 3 \zeta$ & RV & Autologous & $0.2,1,2 \times 10^{8} / \mathrm{m}^{2}$ & NCT00586391 & $\mathrm{BCM}$ & $\mathrm{Xu}(2014)$ [83] \\
\hline CD19 & CLL & 4 & $\mathrm{CD} 28-\mathrm{CD} 3 \zeta$ & $\mathrm{RV}$ & Autologous & $1-4 \times 10^{6} / \mathrm{kg}$ & NCT00924326 & $\mathrm{NCI}$ & $\begin{array}{l}\text { Kochenderfer } \\
(2015)[84]\end{array}$ \\
\hline CD19 & ALL & 21 & $\mathrm{CD} 28-\mathrm{CD} 3 \zeta$ & RV & Autologous & $1,3 \times 10^{6} / \mathrm{kg}$ & NCT01593696 & $\mathrm{NCI}$ & Lee (2015) [85] \\
\hline CD19 & MM & 10 & 4-1BB-CD3 $\zeta$ & LV & Autologous & $1-5 \times 10^{7}$ & NCT02135406 & Upenn & Garfall (2015) [86] \\
\hline CD19 & NHL & $\begin{array}{l}7 \\
19\end{array}$ & $\mathrm{CD} 28-\mathrm{CD} 3 \zeta$ & SBT & Autologous/allogeneic & $\begin{array}{l}1 \times 10^{6} / \mathrm{m}^{2} \\
1 \times 10^{6} / \mathrm{m}^{2}\end{array}$ & $\begin{array}{l}\text { NCT00968760 } \\
\text { NCT01497184 }\end{array}$ & MDACC & $\begin{array}{l}\text { Kebriaei (2016) } \\
\text { [87] }\end{array}$ \\
\hline CD19 & $\begin{array}{l}\text { CLL, SLL, } \\
\text { MM }\end{array}$ & 42 & 4-1BB-CD3乙 & LV & Autologous & $1-5 \times 10^{7 / 8}$ & NCT01747486 & Upenn & Fraietta (2016) [88] \\
\hline $\mathrm{CD} 20$ & $\begin{array}{l}\text { MCL; } \\
\text { B-NHL }\end{array}$ & 3 & $\mathrm{CD} 28-4-1 \mathrm{BB}-\mathrm{CD} 3 \zeta$ & EP & Autologous & $\begin{array}{l}10^{8}, 10^{9}, \\
\quad 3.3 \times 10^{9} / \mathrm{m}^{2}\end{array}$ & NCT00621452 & FHCRC & Till (2012) [89] \\
\hline $\mathrm{CD} 20$ & DLBCL & 7 & 4-1BB-CD3 & LV & Autologous & $\sim 0.3-2.2 \times 10^{7} / \mathrm{kg}$ & NCT01735604 & CPLAGH & Wang (2014) [90] \\
\hline
\end{tabular}

$F L$ follicular lymphoma, $M C L$ mantle cell lymphoma, $C L L$ chronic lymphocytic leukemia, $A L L$ acute lymphoblastic leukemia, $B L$ Burkitt lymphoma, $D L B C L$ diffuse large B cell lymphoma, $H L$ Hodgkin's lymphoma, $N H L$ non-Hodgkins lymphoma, $M M$ multiple myeloma, $E P$ electroporation, $R V$ retrovirus, $L V$ lentivirus, $S B T$ Sleeping Beauty transposition, $B C M$ Baylor College of Medicine, $N C I$ National Cancer Institute, FHCRC Fred Hutchinson Cancer Research Center, UPenn University of Pennsylvania, MSKCC Memorial Sloan Kettering Cancer Center, MDACC MD Anderson Cancer Center, CPLAGH Chinese PLA General Hospital

(B2M)) or indirectly via transcription factors and transporter pathways. B2M is required for successful surface assembly of MHC class I molecules [94], with B2M knockout resulting in cells devoid of major histocompatibility complex-I (MHC-I) expression [95]. Some groups have endeavored to downregulate the $B 2 M$ and $H L A$ loci in primary $\mathrm{T}$ cells $[96,97]$. However, the posttranscriptional nature of this approach leads to a reduction in antigen levels and not necessarily a complete knockdown. This is problematic as it has been demonstrated that a single peptide-MHC complex can trigger $\alpha \beta \mathrm{T}$ cell activation and induce the cytolytic response [98]. With the purpose of generating nonself cells that evade host clearance, Torikai and colleagues genetically engineered donorderived $\mathrm{T}$ cells using designer ZFNs to eliminate expression of HLA-A. HLA-A ${ }^{\text {neg }}$ cells evaded lysis by HLArestricted cytotoxic $\mathrm{T}$ cells, demonstrating conceptually that these modifications have clinical potential as donor-derived 
T cells with a disparate HLA repertoire could be administered to multiple recipients [99].

Another target of interest for improved and sustained CAR T cell effectiveness is PD-1. PD-1 is an immune-checkpoint receptor. Its expression is upregulated following T cell activation, limiting $\mathrm{T}$ cell effector function, and resulting in $\mathrm{T}$ cell exhaustion [100]. Tumor cells upregulate PD-1 ligands leading to diminished immune responses within the tumor microenvironment [101]. As a result, cancer immunotherapeutics have focused on blocking PD-1 activity using monoclonal antibodies [102] and have shown improved efficacy of adoptive CAR T cell therapies [103]. Genome editing however offers a means of permanent deletion of PD-1. This strategy was validated in vitro using primary patient $\mathrm{T}$ cells which demonstrated increased IFN- $\gamma$ production and enhanced cytotoxicity [104]. The June labs successfully edited the HLA, $\alpha$-, and $\beta$-TCR, B2M, and PD- 1 loci using CRISPR with $80 \%$ gene disruption when co-administered with Cas9 mRNA, and over 70\% dual disruption of TCR and HLA-1. These doublenegative cells transduced with CD19-CAR demonstrated potent anti-leukemic activity, demonstrating that simultaneous disruption does not affect CAR T cell efficacy. Moreover, these universal $\mathrm{T}$ cells exhibited reduced alloreactivity and did not induce GvHD in various NSG mouse models [105]. A trial underway in Chengdu China is using CRISPR to produce PD-1 knockout $\mathrm{T}$ cells that are expanded and infused back into patients with resistant and refractory metastatic nonsmall cell lung carcinoma (NCT02793856) [106]. Other proposed trials using CRISPR-mediated PD-1-deficient T cells include those for prostate cancer (NCT02867345), bladder cancer (NCT02863913), and renal cell carcinoma (NCT02867332).

\section{Genome Editing Targeting HIV}

HIV is a single-stranded RNA virus that reverse transcribes RNA to DNA and subsequently integrates into the host genome. It gains cell entry when gp120, an envelope glycoprotein, binds CD4 and co-receptors C-C chemokine receptor 5 (CCR5)(R5), or C-X-C chemokine receptor 4 (CXCR4)(X4). HIV infects a number of immune cells but preferentially replicates within activated $\mathrm{CD} 4^{+} \mathrm{T}$ cells [107]. Over time, there is progressive loss of $\mathrm{CD}^{+}{ }^{+} \mathrm{T}$ cells due to their destruction, rendering the individual immune compromised. Individuals homozygous for the naturally occurring $C C R 5^{\triangle 32}$ mutation are resistant to HIV infection [108-110], making CCR5 a promising therapeutic target. Transplantation from such a donor has been reported to allow effective HIV eradication in a single case, the "Berlin patient" [111]. ZFNs have been used to knockout CCR5 expression in T cells and mediate HIV resistance in vitro with minimal off-target effects $[112,113]$. Mice reconstituted with CCR5-ZFN-modified resting human $\mathrm{CD} 4^{+}$ $\mathrm{T}$ cells, isolated from HIV-1 seronegative individuals, demonstrated resistance when challenged with HIV. Moreover, viral replication was decreased in mice that received CCR5-ZFN-modified T cells of HIV-1 seropositive origin [112]. First-in-human studies assessed the safety of CCR5 ZFNs delivered ex vivo to T cells using adenoviral vector gene transfer [114••]. Infusion of autologous CCR5ZFN-modified $T$ cells into patients with chronic aviremic HIV isnfection was performed with half the cohort continuing antiretroviral therapy (ART) in conjunction with T cell transfusion, while the remainder underwent an interruption in ART treatment. Modified cells persisted for a mean of 48 weeks and had increased stability compared to unmodified $\mathrm{CD} 4^{+} \mathrm{T}$ cells. CCR5 deletion appears to have conferred a survival advantage to $\mathrm{CD} 4^{+} \mathrm{T}$ cells in individuals infected with HIV and expansion and persistence of modified $\mathrm{T}$ cells resulted in improved long-term CD4 counts. Heterozygous CCR $5^{\Delta 32}$ individuals were able to maintain a viral load of either undetectable or up to 1000 copies/ml during interruption of ART treatment [114•.0]. Further studies are ongoing including the ZFNmodified autologous HSCs to determine if CCR5 knockout cells can support HIV-protected immunological reconstitution.

TALENs have also been used to edit the CCR5 co-receptor. Mussolina and colleagues compared ZFNs and TALENs targeting the CCR5 locus within HEK293T cells and demonstrated comparable gene disruption (15-30\%). However, TALENs exhibited lower cytotoxicity and reduced off-target activity at the CCR2 locus [30]. Mock et al. used mRNA electroporation to deliver a CCR5-TALEN, resulting in HIV resistance in knockout cells. This strategy resulted in targeting efficiencies of $>90 \%$ in $\mathrm{CD} 4^{+}$PM1 cells, commonly utilized in HIV infection assays, and $>50 \%$ in primary T cells [115]. Others have developed a megaTAL through substitution of the FokI catalytic domain for a meganuclease which has high intrinsic affinity and specificity [116]. Adeno-associated virus (AAV) delivery of a GFP-encoding donor template for homology-directed insertion at the CCR5 locus was delivered in conjunction with nuclease mRNA. This resulted in $80 \%$ of biallelic alterations and 8-60\% HDR into the CCR5 locus within T cells. Within CD $34^{+}$HSCs, HDR into the CCR5 locus resulted in $14 \%$ modification offering the possibility of targeted gene insertion of C46, an HIV fusion inhibitor than can confer dual protection against R5 and X4-tropic HIV-1 [117]. Targeting of the CCR5 locus using CRISPR/Cas9 has also yielded robust HIV resistance, with mutation efficiencies ranging from 18 to $74.1 \%$ [118-120].

ZFNs specifically targeting the CXCR4 receptor also resulted in T cells resistance to X4-tropic HIV strains in vitro and in vivo, with lower viral titers observed in mice following T cell engraftment $[121,122]$. While this would provide clinical benefit, as X4-tropic HIV is associated with greater pathogenicity and positively correlates with progression to acquired immune deficiency syndrome (AIDS), it was shown 
that CXCR4-ZFN humanized mice lost X4 HIV-1 protectiveness through the emergence of R5-tropic viral mutants [122]. Didigu et al. addressed this issue by simultaneously targeting the CCR5 and CXCR4 coreceptors using ZFNs, resulting in $\mathrm{X} 4$ - and R5-tropic HIV resistant CD4 ${ }^{+} \mathrm{T}$ cells in vitro [123]. An alternative approach was demonstrated by Voit et al. utilized ZFNs to introduce three anti-HIV restriction factors, Rev. M10, TRIM5 $\alpha$, and APOBEC3G D128K into the CCR5 locus, with simultaneous CCR5 knockout and cells exhibited dual R5 and X4 HIV-1 resistance [124]. CRISPR/Cas9 has also been used in studies targeting the CXCR4 locus, with human primary $\mathrm{T}$ cells refractory to subsequent HIV-1 infection [125]. Targets downstream of viral entry have also been exploited with LEDGF, the protein involved in viral integration and encoded by PSIP1, inactivated by TALENs. Modified Jurkat cells demonstrated inhibited HIV-1 integration and severely impaired viral replication [126].

HIV can remain transcriptionally dormant creating latent HIV reservoirs, with alternative strategies designed to target proviral DNA. Wayengera and colleagues used computational modeling to generate a ZFN that would specifically target an 18 bp sequence within the HIV pol gene or 15 other ZFNs targeting other regions of the proviral genome. Lentiviral delivery resulted in abrogation of pol activity and excision of over $80 \%$ of proviral DNA from latently infected cells [127]. The conserved regions of $\mathrm{Gag}$, Pol, and Rev. have been targeted using ZFNs [128]. Others still have targeted the HIV-1 $5^{\prime}$ and $3^{\prime}$ long terminal repeat (LTR), excising fulllength proviral DNA with an efficiency of $45.9 \%$ [129]. Ebina et al. generated two gRNA targets within the TAR sequence of the R-region and within the NF- $\mathrm{kB}$ response element in the U3 region. Efficiency was tested on cells transduced with a lentiviral vector encoding TAT-IRES-GFP under transcriptional regulation of the LTR, with mean fluorescence intensity used to determine gRNA efficiency. The authors noted a reduction of $\mathrm{GFP}^{+}$cells from 45.6 to $20 \%$ using the TARtargeting gRNA [130], while Strong et al. used TALENs targeting the same region resulting in $42 \%$ cleavage [131]. This proviral targeting strategy was mimicked with both TALENs [132] against integrated lentiviral LTRs and CRISPR/Cas9 in single and multiple configuration [133]. The authors identified targets within the viral U3 LTR that resulted in excision of the entire 9709 bp proviral HIV DNA and prevented reinfection within latently infected $\mathrm{T}$ cells [133].

While editing of $\mathrm{T}$ cells had shown promise for HIV resistance, two independent publications demonstrated NHEJmediated viral escape of Cas9/gRNA suppression [134, 135]. Sequencing of escaped viral mutants identified that the mutations clustered around the gRNA target cleavage site where indels are formed. Destruction of the original guide site yielded novel mutations arising in the viral genome through indel formation, and loss of the guide recognition site rendered
CRISPR/Cas therapy ineffective [136]. One alternative to diminish NHEJ-mediated viral escape would be to design multiple target sites within highly conserved regions of the HIV-1 genome. This multiplex approach can yield increased suppression of HIV-1 infection with a decreased GFP intensity, with gRNAs targeted to the LTR shown to be most effective [137]. Finally, recent reports of a designer Brec recombinase efficiently targeting and excising LTRs on scale holds promise for tackling latent proviral HIV [138].

\section{Gene Editing Inherited T Cell Defects}

Primary immunodeficiencies (PIDs) are model disorders for treatment by HSC transplantation and gene therapy although current "gene-addition" approaches have been associated with insertional mutagenesis in some conditions, following viral integration near LMO2 proto-oncogenes, among others, resulting in malignancy [139]. Gene-editing approaches should eventually allow in situ gene repair and stem cellderived reconstitution for SCID disorders and other PIDs. In the first instance, gene repair of $\mathrm{T}$ cells in conditions where cells are present but functionally impaired is being investigated, given the efficiency of editing reagents in these cells. One such condition is HyperIgM syndrome or CD40 ligand deficiency. This defect in cellular immunity renders individuals particularly susceptible to opportunistic infections [140]. Antigen presentation initiates the upregulation and expression of CD40L with its expression finely regulated and activation state dependent. A primary function of CD40L is to convey activation signals to B cells [141]. Mutations within $C D 40 L$ result in an inability to undergo immunoglobulin class switching, the mechanism used in B cells to switch from the production of one immunoglobulin to another [142]. TALEN editing of $C D 40 L$ has yielded successful gene correction within primary $\mathrm{T}$ cells via homology-directed insertion of a recombinant transgene. Inclusion of the region upstream of Exon 1 permitted the maintenance of endogenous regulation, while inclusion of the $3^{\prime}$-UTR conserved posttranscriptional regulation. Edited cells mimicked the response of wild-type T cells in their activation response, while rescuing the class-switching capabilities of B cells in vitro [143]. Kuo et al. have used CRISPR/Cas9 technology to target patient-specific splice-site mutations within exon 3 of $C D 40 L$. A template containing a unique restriction enzyme site was co-electroporated into K562 cells, with HDR confirmed via restriction digest [144]. Other disorders with similar $\mathrm{T}$ cell defects could also be targeted by a similar approach and offer a route to therapy.

While most applications of genome editing rely on gene knockout or HDR, these technologies are also amenable to gene repair without induction of double-stranded DNA breaks; a technology termed "base editing". Komor and colleagues demonstrated that merging the guide RNA-mediated targeting ability of dCas9 or Cas 9 nickase to the cytidine 
deaminase enzyme, APOBEC1, results in the ability of the enzyme to convert cytidine to uridine in a site-specific manner [145]. Single-base editors are particularly attractive for permanent correction of diseases caused by point mutations, such as HIGM1, and broaden the scope of genome editing technologies for clinical applications.

\section{Conclusions}

Genome editing modalities have emerged as fundamental tools with which to modify gene expression in a highly specific manner. Recent clinical successes have shown the utility of genome-edited cell-based therapies, undoubtedly an impetus to treat a wider variety of conditions in the future. Improved genome-editing specificity and design of superior genome editing systems will enhance the translational potential and safety profiles of future $T$ cell-based therapies, further driving the transition from research to clinical translation.

Acknowledgments JD and WQ are supported by the National Institute of Health Research, which also supports the Biomedical Research Centre at UCL Great Ormond Street Institute of Child Health.

\section{Compliance with Ethical Standards}

Conflict of Interest Juliette M.K.M. Delhove declares that she has no conflict of interest. Waseem Qasim reports research funding from Cellectis/Servier, Miltenyi, Bellicum, Calimmune, and Autolus and personal fees from Autolus and Orchard. In addition, Dr. Qasim has patents pending for gene-edited $\mathrm{T}$ cells.

Human and Animal Rights and Informed Consent All procedures performed in studies involving human participants were in accordance with the ethical standards of the institutional and/or national research committee and with the 1964 Helsinki declaration and its later amendments or comparable ethical standards.

Open Access This article is distributed under the terms of the Creative Commons Attribution 4.0 International License (http:// creativecommons.org/licenses/by/4.0/), which permits unrestricted use, distribution, and reproduction in any medium, provided you give appropriate credit to the original author(s) and the source, provide a link to the Creative Commons license, and indicate if changes were made.

\section{References}

Papers of particular interest, published recently, have been highlighted as:

- Of importance

•- Of major importance

1. Dudley ME, Rosenberg SA. Adoptive-cell-transfer therapy for the treatment of patients with cancer. Nat Rev Cancer. 2003;3(9):666-75.

2. Kuball J, Dossett ML, Wolfl M, Ho WY, Voss RH, Fowler C, et al. Facilitating matched pairing and expression of TCR chains introduced into human T cells. Blood. 2007 Mar 15;109(6):2331-8.
3. Kim YG, Cha J, Chandrasegaran S. Hybrid restriction enzymes: zinc finger fusions to Fok I cleavage domain. Proc Natl Acad Sci U S A. 1996 Feb 6;93(3):1156-60.

4. Liang F, Han M, Romanienko PJ, Jasin M. Homologydirected repair is a major double-strand break repair pathway in mammalian cells. Proc Natl Acad Sci U S A. 1998 Apr 28;95(9):5172-7.

5. Hefferin ML, Tomkinson AE. Mechanism of DNA double-strand break repair by non-homologous end joining. DNA repair. 2005;4(6):639-48.

6. Nagy E, Maquat LE. A rule for termination-codon position within intron-containing genes: when nonsense affects RNA abundance. Trends Biochem Sci. 1998;23(6):198-9.

7. Thompson AJ, Yuan X, Kudlicki W, Herrin DL. Cleavage and recognition pattern of a double-strand-specific endonuclease (ICreI) encoded by the chloroplast $23 \mathrm{~S}$ rRNA intron of Chlamydomonas reinhardtii. Gene. 1992;119(2):247-51.

8. Turmel M, Otis C, Cote V, Lemieux C. Evolutionarily conserved and functionally important residues in the I-CeuI homing endonuclease. Nucleic Acids Res. 1997 Jul 1;25(13):2610-9.

9. Duan X, Gimble FS, Quiocho FA. Crystal structure of PI-SceI, a homing endonuclease with protein splicing activity. Cell. 1997;89(4):555-64.

10. Bertoni C. Emerging gene editing strategies for Duchenne muscular dystrophy targeting stem cells. Front Physiol. 2014;5:148. doi: 10.3389/fphys.2014.00148.

11. Didigu CA, Doms RW. Novel approaches to inhibit HIV entry. Viruses. 2012;4(2):309-24. doi:10.3390/v4020309.

12. Hyongbum K, Jin-Soo K. A guide to genome engineering with programmable nucleases. Nat Rev Genet. 2014;15:321-34. doi: $10.1038 / \mathrm{nrg} 3686$.

13. Agrotis A, Ketteler R. A new age in functional genomics using CRISPR/Cas9 in arrayed library screening. Front Genet. 2015;6: 300. doi:10.3389/fgene.2015.00300.

14. Chevalier BS, Monnat RJ, Stoddard BL. The homing endonuclease I-CreI uses three metals, one of which is shared between the two active sites. Nat Struct Mol Biol. 2001;8(4):312-6.

15. Brown AE, MacLeod DT, Martin AJ, Wetzel KJ, Pham CD, Antony $\mathrm{J}$, et al. $\mathrm{T}$ cell receptor knockout efficiency utilizing an engineered meganuclease is influenced by stimulation conditions. J Immunol. 2016;196(1 Supplement):138.2.

16. Grosse S, Huot N, Mahiet C, Arnould S, Barradeau S, Le Clerre D, et al. Meganuclease-mediated inhibition of HSV1 infection in cultured cells. Mol Ther. 2011;19(4):694-702.

17. Silva G, Poirot L, Galetto R, Smith J, Montoya G, Duchateau P, et al. Meganucleases and other tools for targeted genome engineering: perspectives and challenges for gene therapy. Curr Gene Ther. 2011 Feb;11(1):11-27.

18. Grizot S, Smith J, Daboussi F, Prieto J, Redondo P, Merino N, et al. Efficient targeting of a SCID gene by an engineered singlechain homing endonuclease. Nucleic Acids Res. 2009 Sep;37(16): 5405-19.

19. Arnould S, Perez C, Cabaniols J, Smith J, Gouble A, Grizot S, et al. Engineered I-CreI derivatives cleaving sequences from the human XPC gene can induce highly efficient gene correction in mammalian cells. J Mol Biol. 2007;371(1):49-65.

20. Doyon Y, Vo TD, Mendel MC, Greenberg SG, Wang J, Xia DF, et al. Enhancing zinc-finger-nuclease activity with improved obligate heterodimeric architectures. Nat Methods. 2011;8(1):74-9.

21. Pavletich NP, Pabo CO. Zinc finger-DNA recognition: crystal structure of a Zif268-DNA complex at 2.1 A. Science. 1991 May 10;252(5007):809-17.

22. Wolfe SA, Nekludova L, Pabo CO. DNA recognition by Cys2His2 zinc finger proteins. Annu Rev Biophys Biomol Struct. 2000;29(1):183-212. 
23. Pattanayak V, Ramirez CL, Joung JK, Liu DR. Revealing offtarget cleavage specificities of zinc-finger nucleases by in vitro selection. Nat Methods. 2011;8(9):765-70.

24. Sharma R, Anguela XM, Doyon Y, Wechsler T, DeKelver RC, Sproul S, et al. In vivo genome editing of the albumin locus as a platform for protein replacement therapy. Blood. 2015 Oct 8;126(15):1777-84.

25. Moscou MJ, Bogdanove AJ. A simple cipher governs DNA recognition by TAL effectors. Science. 2009 Dec 11;326(5959):1501.

26. Boch J, Scholze H, Schornack S, Landgraf A, Hahn S, Kay S, et al. Breaking the code of DNA binding specificity of TAL-type III effectors. Science. 2009 Dec 11;326(5959):1509-12.

27. Cong L, Zhou R, Kuo Y, Cunniff M, Zhang F. Comprehensive interrogation of natural TALE DNA-binding modules and transcriptional repressor domains. Nat Commun. 2012;3:968.

28. Miller JC, Zhang L, Xia DF, Campo JJ, Ankoudinova IV, Guschin DY, et al. Improved specificity of TALE-based genome editing using an expanded RVD repertoire. Nat Methods. 2015;12(5): 465-71.

29. Chen S, Oikonomou G, Chiu CN, Niles BJ, Liu J, Lee DA, et al. A large-scale in vivo analysis reveals that TALENs are significantly more mutagenic than ZFNs generated using context-dependent assembly. Nucleic Acids Res. 2013 Feb 1;41(4):2769-78.

30. Mussolino C, Alzubi J, Fine EJ, Morbitzer R, Cradick TJ, Lahaye $\mathrm{T}$, et al. TALENs facilitate targeted genome editing in human cells with high specificity and low cytotoxicity. Nucleic Acids Res. 2014 Jun;42(10):6762-73.

31. Benjamin R, Berges BK, Solis-Leal A, Igbinedion O, Strong CL, Schiller MR. TALEN gene editing takes aim on HIV. Hum Genet. 2016:1-12.

32. Menger L, Gouble A, Marzolini MA, Pachnio A, Bergerhoff K, Henry JY, et al. TALEN-mediated genetic inactivation of the glucocorticoid receptor in cytomegalovirus-specific T cells. Blood. 2015 Dec 24;126(26):2781-9.

33.•• Qasim W, Zhan H, Samarasinghe S, Adams S, Amrolia P, Stafford $\mathrm{S}$, et al. Molecular remission of infant B-ALL after infusion of universal TALEN gene-edited CAR T cells. Sci Transl Med. 2017 Jan 25;9(374). doi:10.1126/scitranslmed.aaj2013. First clinical report using cells edited with TALENs in a patient with leukemia.

34. Holkers M, Maggio I, Liu J, Janssen JM, Miselli F, Mussolino C, et al. Differential integrity of TALE nuclease genes following adenoviral and lentiviral vector gene transfer into human cells. Nucleic Acids Res. 2013 Mar 1;41(5):e63.

35. Ran FA, Hsu PD, Wright J, Agarwala V, Scott DA, Zhang F. Genome engineering using the CRISPR-Cas9 system. Nat Protocols. 2013;8(11):2281-308. Paper describing the utility of CRISPR/Cas9 as a genome editing tool.

36. Zetsche B, Gootenberg JS, Abudayyeh OO, Slaymaker IM, Makarova KS, Essletzbichler P, et al. Cpfl is a single RNAguided endonuclease of a class 2 CRISPR-Cas system. Cell. 2015;163(3):759-71.

37. Gao F, Shen XZ, Jiang F. Wu Y, Han C. Nat Biotechnol: DNAguided genome editing using the Natronobacterium gregoryi Argonaute; 2016.

38. Cong L, Zhang F. Genome engineering using CRISPR-Cas9 system. Methods Mol Biol. 2015;1239:197-217.

39.• Jinek M, Chylinski K, Fonfara I, Hauer M, Doudna JA, Charpentier E. A programmable dual-RNA-guided DNA endonuclease in adaptive bacterial immunity. Science. 2012;337(6096):816-21. Description of CRISPR/Cas system.

40.• Mali P, Esvelt KM, Church GM. Cas9 as a versatile tool for engineering biology. Nat Methods. 2013;10(10):957-63. Application of CRISPR for gene editing.

41. Deltcheva E, Chylinski K, Sharma CM, Gonzales K, Chao Y, Pirzada ZA, et al. CRISPR RNA maturation by trans-encoded small RNA and host factor RNase III. Nature. 2011 Mar 31;471(7340):602-7.

42. Gilbert LA, Larson MH, Morsut L, Liu Z, Brar GA, Torres SE, et al. CRISPR-mediated modular RNA-guided regulation of transcription in eukaryotes. Cell. 2013;154(2):442-51.

43. Sander JD, Joung JK. CRISPR-Cas systems for editing, regulating and targeting genomes. Nat Biotechnol. 2014;32(4):347-55.

44. First-in-human CRISPR trial. Nat Biotech. 2016;34(8):796.

45. Xu C, Gagnon E, Call ME, Schnell JR, Schwieters CD, Carman $\mathrm{CV}$, et al. Regulation of $\mathrm{T}$ cell receptor activation by dynamic membrane binding of the $\mathrm{CD} 3 \varepsilon$ cytoplasmic tyrosine-based motif. Cell. 2008;135(4):702-13.

46. Lineberry N, Fathman GC. T cell Anergy: where It's LAT. Immunity. 2006;24(5):501-3.

47. Juno Therapeutics. Chimeric Antigen Receptor Technology (CARs). https://www.junotherapeutics.com/our-science/cartechnology/. Accessed 24 Nov 2016.

48. Morgan RA, Dudley ME, Wunderlich JR, Hughes MS, Yang JC, Sherry RM, et al. Cancer regression in patients after transfer of genetically engineered lymphocytes. Science. 2006 Oct 6;314(5796):126-9.

49. Johnson LA, Morgan RA, Dudley ME, Cassard L, Yang JC, Hughes MS, et al. Gene therapy with human and mouse T-cell receptors mediates cancer regression and targets normal tissues expressing cognate antigen. Blood. 2009 Jul 16;114(3):535-46.

50. Robbins PF, Morgan RA, Feldman SA, Yang JC, Sherry RM, Dudley ME, et al. Tumor regression in patients with metastatic synovial cell sarcoma and melanoma using genetically engineered lymphocytes reactive with NY-ESO-1. J Clin Oncol. 2011 Mar 1;29(7):917-24.

51. Rapoport AP, Stadtmauer EA, Binder-Scholl GK, Goloubeva O, Vogl DT, Lacey SF, et al. NY-ESO-1-specific TCR-engineered T cells mediate sustained antigen-specific antitumor effects in myeloma. Nat Med. 2015;21(8):914-21. First report of TCR therapy in humans using lentiviral delivery that has shown persistence past one month.

52. Morgan RA, Chinnasamy N, Abate-Daga D, Gros A, Robbins PF, Zheng Z, et al. Cancer regression and neurological toxicity following anti-MAGE-A3 TCR gene therapy. J Immunother. 2013 Feb;36(2):133-51

53. Shao H, Zhang W, Hu Q, Wu F, Shen H, Huang S. TCR mispairing in genetically modified $\mathrm{T}$ cells was detected by fluorescence resonance energy transfer. Mol Biol Rep. 2010;37(8): 3951-6.

54. Govers C, Sebestyén Z, Coccoris M, Willemsen RA, Debets R. T cell receptor gene therapy: strategies for optimizing transgenic TCR pairing. Trends Mol Med. 2010;16(2):77-87.

55. Torikai H, Reik A, Liu PQ, Zhou Y, Zhang L, Maiti S, et al. A foundation for universal T-cell based immunotherapy: $\mathrm{T}$ cells engineered to express a CD19-specific chimeric-antigen-receptor and eliminate expression of endogenous TCR. Blood. 2012 Jun 14;119(24):5697-705.

56. Provasi E, Genovese P, Lombardo A, Magnani Z, Liu P, Reik A, et al. Editing $\mathrm{T}$ cell specificity towards leukemia by zinc finger nucleases and lentiviral gene transfer. Nat Med. 2012;18(5):80715.

57. Berdien B, Mock U, Atanackovic D, Fehse B. TALEN-mediated editing of endogenous T-cell receptors facilitates efficient reprogramming of $\mathrm{T}$ lymphocytes by lentiviral gene transfer. Gene Ther. 2014;21(6):539-48.

58. Poirot L, Philip B, Schiffer-Mannioui C, Le Clerre D, ChionSotinel I, Derniame S, et al. Multiplex genome-edited T-cell manufacturing platform for "off-the-shelf" adoptive T-cell immunotherapies. Cancer Res. 2015 Sep 15;75(18):3853-64.

59. Osborn MJ, Webber BR, Knipping F, Lonetree C, Tennis N, DeFeo AP, et al. Evaluation of TCR gene editing achieved by 
TALENs, CRISPR/Cas9, and megaTAL nucleases. Mol Ther. 2015.

60. Hicklin DJ, Marincola FM, Ferrone S. HLA class I antigen downregulation in human cancers: T-cell immunotherapy revives an old story. Mol Med Today. 1999;5(4):178-86.

61. Kuwana Y, Asakura Y, Utsunomiya N, Nakanishi M, Arata Y, Itoh $\mathrm{S}$, et al. Expression of chimeric receptor composed of immunoglobulin-derived V resions and T-cell receptor-derived C regions. Biochem Biophys Res Commun. 1987;149(3):960-8.

62. Gross G, Waks T, Eshhar Z. Expression of immunoglobulin-T-cell receptor chimeric molecules as functional receptors with antibodytype specificity. Proc Natl Acad Sci U S A. 1989 Dec;86(24): 10024-8.

63. Eshhar Z, Waks T, Gross G, Schindler DG. Specific activation and targeting of cytotoxic lymphocytes through chimeric single chains consisting of antibody-binding domains and the gamma or zeta subunits of the immunoglobulin and T-cell receptors. Proc Natl Acad Sci U S A. 1993 Jan 15;90(2):720-4.

64. Irving BA, Weiss A. The cytoplasmic domain of the T cell receptor $\zeta$ chain is sufficient to couple to receptor-associated signal transduction pathways. Cell. 1991;64(5):891-901.

65. Curran KJ, Pegram HJ, Brentjens RJ. Chimeric antigen receptors for T cell immunotherapy: current understanding and future directions. J Gene Med. 2012;14(6):405-15.

66. Mitsuyasu RT, Anton PA, Deeks SG, Scadden DT, Connick E, Downs MT, et al. Prolonged survival and tissue trafficking following adoptive transfer of CD4zeta gene-modified autologous CD4(+) and CD8(+) T cells in human immunodeficiency virusinfected subjects. Blood. 2000 Aug 1;96(3):785-93.

67. Kershaw MH, Westwood JA, Parker LL, Wang G, Eshhar Z, Mavroukakis SA, et al. A phase I study on adoptive immunotherapy using gene-modified T cells for ovarian cancer. Clin Cancer Res. 2006 Oct 15;12(20 Pt 1):6106-15.

68. Lamers CH, Sleijfer S, Vulto AG, Kruit WH, Kliffen M, Debets R, et al. Treatment of metastatic renal cell carcinoma with autologous T-lymphocytes genetically retargeted against carbonic anhydrase IX: first clinical experience. J Clin Oncol. 2006 May 1;24(13): e20-2.

69. Kochenderfer JN, Wilson WH, Janik JE, Dudley ME, StetlerStevenson M, Feldman SA, et al. Eradication of B-lineage cells and regression of lymphoma in a patient treated with autologous $\mathrm{T}$ cells genetically engineered to recognize CD19. Blood. 2010 Nov 18;116(20):4099-102.

70. Kalos M, Levine BL, Porter DL, Katz S, Grupp SA, Bagg A, et al. $\mathrm{T}$ cells with chimeric antigen receptors have potent antitumor effects and can establish memory in patients with advanced leukemia. Sci Transl Med. 2011;3(95):95ra73.

71. Brentjens RJ, Davila ML, Riviere I, Park J, Wang X, Cowell LG, et al. CD19-targeted T cells rapidly induce molecular remissions in adults with chemotherapy-refractory acute lymphoblastic leukemia. Sci Transl Med. 2013;5(177):177ra38.

72. Huls H, Singh H, Olivares S, Figliola M, Kumar PR, Jena B, et al. First clinical trials employing sleeping beauty gene transfer system and artificial antigen presenting cells to generate and infuse T cells expressing CD19-specific chimeric antigen receptor. Blood. 2013;122(21):166.

73. Field A, Qasim W. Engineered T cell therapies. Expert Rev Mol Med. 2015;17:e19.

74. Holzinger A, Barden M, Abken H. The growing world of CAR T cell trials: a systematic review. Cancer Immunol Immunother. 2016:1-18.

75. Jensen MC, Popplewell L, Cooper LJ, DiGiusto D, Kalos M, Ostberg JR, et al. Antitransgene rejection responses contribute to attenuated persistence of adoptively transferred CD20/CD19specific chimeric antigen receptor redirected $\mathrm{T}$ cells in humans.
Biology of Blood and Marrow Transplantation. 2010;16(9):124556.

76. Savoldo B, Ramos CA, Liu E, Mims MP, Keating MJ, Carrum G, et al. CD28 costimulation improves expansion and persistence of chimeric antigen receptor-modified T cells in lymphoma patients. J Clin Invest. 2011 May;121(5):1822-6.

77. Brentjens RJ, Riviere I, Park JH, Davila ML, Wang X, Stefanski J, et al. Safety and persistence of adoptively transferred autologous CD19-targeted $\mathrm{T}$ cells in patients with relapsed or chemotherapy refractory B-cell leukemias. Blood. 2011 Nov 3;118(18):4817-28.

78. Porter DL, Levine BL, Kalos M, Bagg A, June CH. Chimeric antigen receptor-modified $\mathrm{T}$ cells in chronic lymphoid leukemia. N Engl J Med. 2011;365(8):725-33.

79. Kochenderfer JN, Dudley ME, Feldman SA, Wilson WH, Spaner $\mathrm{DE}$, Maric I, et al. B-cell depletion and remissions of malignancy along with cytokine-associated toxicity in a clinical trial of antiCD19 chimeric-antigen-receptor-transduced T cells. Blood. 2012 Mar 22;119(12):2709-20.

80. Kochenderfer JN, Dudley ME, Carpenter RO, Kassim SH, Rose JJ, Telford WG, et al. Donor-derived CD19-targeted T cells cause regression of malignancy persisting after allogeneic hematopoietic stem cell transplantation. Blood. 2013 Dec 12;122(25):4129-39.

81. Cruz CR, Micklethwaite KP, Savoldo B, Ramos CA, Lam S, Ku $\mathrm{S}$, et al. Infusion of donor-derived CD19-redirected virus-specific $\mathrm{T}$ cells for B-cell malignancies relapsed after allogeneic stem cell transplant: a phase 1 study. Blood. 2013 Oct 24;122(17):2965-73.

82. Maude SL, Frey N, Shaw PA, Aplenc R, Barrett DM, Bunin NJ, et al. Chimeric antigen receptor T cells for sustained remissions in leukemia. N Engl J Med. 2014;371(16):1507-17. Lentiviral CAR19 therapy in leukemia.

83. Xu Y, Zhang M, Ramos CA, Durett A, Liu E, Dakhova O, et al. Closely related T-memory stem cells correlate with in vivo expansion of CAR.CD19-T cells and are preserved by IL-7 and IL-15. Blood. 2014 Jun 12;123(24):3750-9.

84. Kochenderfer JN, Dudley ME, Kassim SH, Somerville RP, Carpenter RO, Stetler-Stevenson M, et al. Chemotherapyrefractory diffuse large B-cell lymphoma and indolent B-cell malignancies can be effectively treated with autologous $\mathrm{T}$ cells expressing an anti-CD19 chimeric antigen receptor. J Clin Oncol. 2015 Feb 20;33(6):540-9.

85. Lee DW, Kochenderfer JN, Stetler-Stevenson M, Cui YK, Delbrook C, Feldman SA, et al. T cells expressing CD19 chimeric antigen receptors for acute lymphoblastic leukaemia in children and young adults: a phase 1 dose-escalation trial. Lancet. 2015;385(9967):517-28.

86. Garfall AL, Maus MV, Hwang W, Lacey SF, Mahnke YD, Melenhorst JJ, et al. Chimeric antigen receptor T cells against CD19 for multiple myeloma. N Engl J Med. 2015;373(11): 1040-7.

87. Kebriaei P, Singh H, Huls MH, Figliola MJ, Bassett R, Olivares S, et al. Phase I trials using sleeping beauty to generate CD19specific CAR T cells. J Clin Invest. 2016;126(9):3363-76.

88. Fraietta JA, Beckwith KA, Patel PR, Ruella M, Zheng Z, Barrett $\mathrm{DM}$, et al. Ibrutinib enhances chimeric antigen receptor T-cell engraftment and efficacy in leukemia. Blood. 2016 Mar 3;127(9):1117-27.

89. Till BG, Jensen MC, Wang J, Qian X, Gopal AK, Maloney DG, et al. CD20-specific adoptive immunotherapy for lymphoma using a chimeric antigen receptor with both CD28 and 4-1BB domains: pilot clinical trial results. Blood. 2012 Apr 26;119(17): 3940-50.

90. Wang Y, Zhang W, Han Q, Liu Y, Dai H, Guo Y, et al. Effective response and delayed toxicities of refractory advanced diffuse large B-cell lymphoma treated by CD20-directed chimeric antigen receptor-modified T cells. Clin Immunol. 2014;155(2):160-75. 
91. Gouble A, Philip B, Poirot L, Schiffer-Mannioui C, Galetto R, Derniame $\mathrm{S}$, et al. In vivo proof of concept of activity and safety of UCART19, an allogeneic "off-the-shelf" adoptive T-cell immunotherapy against CD19 B-cell Leukemias. Blood. 2014;124(21): 4689.

92. Hale G. The CD52 antigen and development of the CAMPATH antibodies. Cytotherapy. 2001;3(3):137-43.

93. Morishima Y, Sasazuki T, Inoko H, Juji T, Akaza T, Yamamoto K, et al. The clinical significance of human leukocyte antigen (HLA) allele compatibility in patients receiving a marrow transplant from serologically HLA-A, HLA-B, and HLA-DR matched unrelated donors. Blood. 2002 Jun 1;99(11):4200-6.

94. Gussow D, Rein R, Ginjaar I, Hochstenbach F, Seemann G, Kottman A, et al. The human beta 2-microglobulin gene. Primary structure and definition of the transcriptional unit. J Immunol. 1987 Nov 1;139(9):3132-8.

95. Zijlstra M, Bix M, Simister NE, Loring JM, Raulet DH, Jaenisch R. Beta 2-Microglobulin deficient mice lack CD4-8+ cytolytic T cells. Nature. 1990;344(6268):742-6.

96. Figueiredo C, Seltsam A, Blasczyk R. Class-, gene-, and groupspecific HLA silencing by lentiviral shRNA delivery. J Mol Med. 2006;84(5):425-37.

97. Permanent, lowered HLA class I expression using lentivirus vectors with shRNA constructs: averting cytotoxicity by alloreactive T lymphocytes. Transplantation proceedings: Elsevier; 2006.

98. Sykulev Y, Joo M, Vturina I, Tsomides TJ, Eisen HN. Evidence that a single peptide-MHC complex on a target cell can elicit a cytolytic T cell response. Immunity. 1996;4(6):565-71.

99. Torikai H, Reik A, Soldner F, Warren EH, Yuen C, Zhou Y, et al. Toward eliminating HLA class I expression to generate universal cells from allogeneic donors. Blood. 2013 Aug 22;122(8):1341-9.

100. Agata Y, Kawasaki A, Nishimura H, Ishida Y, Tsubata T, Yagita H, et al. Expression of the PD-1 antigen on the surface of stimulated mouse T and B lymphocytes. Int Immunol. 1996 May;8(5):76572.

101. Blank C, Gajewski TF, Mackensen A. Interaction of PD-L1 on tumor cells with PD-1 on tumor-specific T cells as a mechanism of immune evasion: implications for tumor immunotherapy. Cancer Immunol Immunother. 2005;54(4):307-14.

102. Brahmer JR, Drake CG, Wollner I, Powderly JD, Picus J, Sharfman WH, et al. Phase I study of single-agent anti-programmed death-1 (MDX-1106) in refractory solid tumors: safety, clinical activity, pharmacodynamics, and immunologic correlates. J Clin Oncol. 2010 Jul 1;28(19):3167-75.

103. John LB, Kershaw MH, Darcy PK. Blockade of PD-1 immunosuppression boosts CAR T-cell therapy. Oncoimmunology. 2013;2(10):e26286.

104. Su S, Hu B, Shao J, Shen B, Du J, Du Y, et al. CRISPR-Cas9 mediated efficient PD-1 disruption on human primary $\mathrm{T}$ cells from cancer patients. Sci Rep. 2016 Jan 28;6:20070.

105. Ren J, Liu X, Fang C, Jiang S, June CH, Zhao Y. Multiplex Cripsr/ Cas9 genome editing to generate potent universal CART and PD1deficient cells against leukemia. Blood. 2015;126(23):4280.

106. Cyranoski D. Chinese scientists to pioneer first human CRISPR trial. Nature. 2016;535:476-7.

107. Douek D, Brenchley J, Betts M, Ambrozak D, Hill B, Okamoto Y, et al. HIV preferentially infects HIV-specific CD4 T cells. Nature. 2002;417:95-8

108. Huang Y, Paxton WA, Wolinsky SM, Neumann AU, Zhang L, He $\mathrm{T}$, et al. The role of a mutant CCR5 allele in HIV-1 transmission and disease progression. Nat Med. 1996;2(11):1240-3.

109. Samson M, Libert F, Doranz BJ, Rucker J, Liesnard C, Farber $\mathrm{CM}$, et al. Resistance to HIV-1 infection in caucasian individuals bearing mutant alleles of the CCR- 5 chemokine receptor gene. Nature. 1996 Aug 22;382(6593):722-5.
110. Liu R, Paxton WA, Choe S, Ceradini D, Martin SR, Horuk R, et al. Homozygous defect in HIV-1 coreceptor accounts for resistance of some multiply-exposed individuals to HIV-1 infection. Cell. 1996;86(3):367-77.

111. Hütter G, Nowak D, Mossner M, Ganepola S, Müßig A, Allers K, et al. Long-term control of HIV by CCR5 Delta32/Delta32 stemcell transplantation. N Engl J Med. 2009;360(7):692-8.

112. Yi G, Choi JG, Bharaj P, Abraham S, Dang Y, Kafri T, et al. CCR5 gene editing of resting CD4 T cells by transient ZFN expression from HIV envelope pseudotyped nonintegrating lentivirus confers HIV-1 resistance in humanized mice. Molecular TherapyNucleic Acids. 2014;3(9):e198.

113. Perez EE, Wang J, Miller JC, Jouvenot Y, Kim KA, Liu O, et al. Establishment of HIV-1 resistance in CD4 T cells by genome editing using zinc-finger nucleases. Nat Biotechnol. 2008;26(7): 808-16.

114.• Tebas P, Stein D, Tang WW, Frank I, Wang SQ, Lee G, et al. Gene editing of CCR5 in autologous CD4 T cells of persons infected with HIV. N Engl J Med. 2014;370(10):901-10. First clinical study using proprietary ZFNs to target HIV in patient T-cells.

115. Mock U, Machowicz R, Hauber I, Horn S, Abramowski P, Berdien B, et al. mRNA transfection of a novel TAL effector nuclease (TALEN) facilitates efficient knockout of HIV coreceptor CCR5. Nucleic Acids Res. 2015 Jun 23;43(11):5560-71.

116. Boissel S, Jarjour J, Astrakhan A, Adey A, Gouble A, Duchateau $\mathrm{P}$, et al. megaTALs: a rare-cleaving nuclease architecture for therapeutic genome engineering. Nucleic Acids Res. 2014 Feb;42(4): 2591-601.

117. Sather BD, Romano Ibarra GS, Sommer K, Curinga G, Hale M, Khan IF, et al. Efficient modification of CCR5 in primary human hematopoietic cells using a megaTAL nuclease and AAV donor template. Sci Transl Med. 2015;7(307):307ra156.

118. Cho SW, Kim S, Kim JM, Kim J. Targeted genome engineering in human cells with the Cas9 RNA-guided endonuclease. Nat Biotechnol. 2013;31(3):230-2.

119. Li C, Guan X, Du T, Jin W, Wu B, Liu Y, et al. Inhibition of HIV-1 infection of primary CD4 T-cells by gene editing of CCR 5 using adenovirus-delivered CRISPR/Cas9. J Gen Virol. 2015;96(8): 2381-93.

120. Mandal PK, Ferreira LM, Collins R, Meissner TB, Boutwell CL, Friesen M, et al. Efficient ablation of genes in human hematopoietic stem and effector cells using CRISPR/Cas9. Cell Stem Cell. 2014;15(5):643-52.

121. Yuan J, Wang J, Crain K, Fearns C, Kim KA, Hua KL, et al. Zincfinger nuclease editing of human cxcr4 promotes HIV-1 CD4+ T cell resistance and enrichment. Mol Ther. 20(4):849-59.

122. Wilen CB, Wang J, Tilton JC, Miller JC, Kim KA, Rebar EJ, et al. Engineering HIV-resistant human CD4+ T cells with CXCR4specific zinc-finger nucleases. PLoS Pathog. 2011;7(4):e1002020.

123. Didigu CA, Wilen CB, Wang J, Duong J, Secreto AJ, DanetDesnoyers GA, et al. Simultaneous zinc-finger nuclease editing of the HIV coreceptors ccr5 and cxcr4 protects CD4+ T cells from HIV-1 infection. Blood. 2014 Jan 2;123(1):61-9.

124. Voit RA, McMahon MA, Sawyer SL, Porteus MH. Generation of an HIV resistant T-cell line by targeted "stacking" of restriction factors. Mol Ther. 2013;21(4):786-95.

125. Hou P, Chen S, Wang S, Yu X, Chen Y, Jiang M, et al. Genome editing of CXCR4 by CRISPR/cas9 confers cells resistant to HIV1 infection. Sci Rep. 2015 Oct 20;5:15577.

126. Fadel HJ, Morrison JH, Saenz DT, Fuchs JR, Kvaratskhelia M, Ekker SC, et al. TALEN knockout of the PSIP1 gene in human cells: analyses of HIV-1 replication and allosteric integrase inhibitor mechanism. J Virol. 2014 Sep 1;88(17):9704-17.

127. Wayengera M. Proviral HIV-genome-wide and pol-gene specific zinc finger nucleases: usability for targeted HIV gene therapy. Theor Biol Med Model. 2011;8(1):1. 
128. Engineered zinc finger nucleases to inactivate the HIV genome. Proceedings of the 19th HIV International Conference, Washington DC, USA; 2012.

129. Qu X, Wang P, Ding D, Li L, Wang H, Ma L, et al. Zinc-fingernucleases mediate specific and efficient excision of HIV-1 proviral DNA from infected and latently infected human T cells. Nucleic Acids Res. 2013 Sep;41(16):7771-82.

130. Ebina H, Misawa N, Kanemura Y, Koyanagi Y. Harnessing the CRISPR/Cas9 system to disrupt latent HIV-1 provirus. Scientific reports. 2013;3

131. Strong CL, Guerra HP, Mathew KR, Roy N, Simpson LR, Schiller MR. Damaging the integrated HIV proviral DNA with TALENs. PLoS One. 2015;10(5):e0125652.

132. Ebina H, Kanemura Y, Misawa N, Sakuma T, Kobayashi T, Yamamoto T, et al. A high excision potential of TALENs for integrated DNA of HIV-based lentiviral vector. PLoS One. 2015;10(3):e0120047.

133. Hu W, Kaminski R, Yang F, Zhang Y, Cosentino L, Li F, et al. RNA-directed gene editing specifically eradicates latent and prevents new HIV-1 infection. Proc Natl Acad Sci U S A. 2014 Aug 5;111(31):11461-6.

134. Wang G, Zhao N, Berkhout B, Das AT. CRISPR-Cas9 can inhibit HIV-1 replication but NHEJ repair facilitates virus escape. Mol Ther. 2016.

135. Wang Z, Pan Q, Gendron P, Zhu W, Guo F, Cen S, et al. CRISPR/ Cas9-derived mutations both inhibit HIV-1 replication and accelerate viral escape. Cell Rep. 2016;15(3):481-9.

136. Liang C, Wainberg MA, Das AT, Berkhout B. CRISPR/Cas9: a double-edged sword when used to combat HIV infection. Retrovirology. 2016;13(1):1.

137. Liao H, Gu Y, Diaz A, Marlett J, Takahashi Y, Li M, et al. Use of the CRISPR/Cas9 system as an intracellular defense against HIV-1 infection in human cells. Nat Commun. 2015;6
138. Karpinski J, Hauber I, Chemnitz J, Schäfer C, Paszkowski-Rogacz $\mathrm{M}$, Chakraborty D, et al. Directed evolution of a recombinase that excises the provirus of most HIV-1 primary isolates with high specificity. Nat Biotechnol. 2016;34(4):401-9.

139. Hacein-Bey-Abina S, Garrigue A, Wang GP, Soulier J, Lim A, Morillon E, et al. Insertional oncogenesis in 4 patients after retrovirus-mediated gene therapy of SCID-X1. J Clin Invest. 2008 Sep;118(9):3132-42.

140. Subauste CS, Wessendarp M, Sorensen RU, Leiva LE. CD40CD40 ligand interaction is central to cell-mediated immunity against toxoplasma gondii: patients with hyper IgM syndrome have a defective type 1 immune response that can be restored by soluble CD40 ligand trimer. J Immunol. 1999 Jun 1;162(11): 6690-700.

141. Lane P, Traunecker A, Hubele S, Inui S, Lanzavecchia A, Gray D. Activated human $\mathrm{T}$ cells express a ligand for the human B cellassociated antigen CD40 which participates in T cell-dependent activation of B lymphocytes. Eur J Immunol. 1992;22(10):25738

142. Fuleihan R, Ramesh N, Loh R, Jabara H, Rosen RS, Chatila T, et al. Defective expression of the CD40 ligand in X chromosomelinked immunoglobulin deficiency with normal or elevated IgM. Proc Natl Acad Sci U S A. 1993 Mar 15;90(6):2170-3.

143. Hubbard N, Hagin D, Sommer K, Song Y, Khan I, Clough C, et al. Targeted gene editing restores regulated CD40L function in Xlinked hyper-IgM syndrome. Blood. 2016 May 26;127(21): 2513-22.

144. Kuo CY, Hoban MD, Joglekar AV, Kohn DB. Site specific Gene correction of defects in CD40 ligand using the Crispr/Cas9 genome editing platform. J Allergy Clin Immunol. 2015;135(2): AB17.

145. Komor AC, Kim YB, Packer MS, Zuris JA, Liu DR. Programmable editing of a target base in genomic DNA without double-stranded DNA cleavage. Nature. 2016. 